\title{
PEMUPUKAN PADA BUDIDAYA BAWANG MERAH SPESIFIK LOKASI PADA LAHAN PASIR
}

\author{
Fertilization on Shallot Cultivation in Specific Location on Sandy Land
}

\author{
Sutardi \\ Peneliti Balai Pengkajian Teknologi Pertanian Yogyakarta \\ J1. Stadion Baru No. 22, Wedomartani, Ngemplak, Wedomartani, Sleman, \\ Kabupaten Sleman, Daerah Istimewa Yogyakarta 55584
}

Alamat Korespondensi: s.pd_sutardi@yahoo.co.id

\begin{abstract}
ABSTRAK
Kalium merupakan salah satu unsur hara kunci keberhasilan dalam mendukung produksi bawang merah spesifik lokasi di lahan pasir selatan. Tujuan penelitian untuk mengetahui dosis optimal pupuk kalium pada bawang merah spesifik lokasi lahan pasir. Penelitian dilaksanakan selama dua musim kemarau pada bulan Juni-September 2015 dan Juni-September 2016 di lokasi Kelompok Tani Manunggal, Desa Srigading, Kecamatan Sanden, Kabupaten Bantul (07 59' 8659” S, $110^{\circ} 15^{\prime}$ 6753” E). Penelitian menggunakan Rancangan Acak Kelompok faktor tunggal dengan pendekatan Minus One Test yang terdiri dari 7 taraf dan kontrol diulang 3 kali. Respon pemupukan kalium menggunakan Rancangan Acak Kelompok dengan 5 perlakuan tingkat dosis 0, 75, 150, 225, dan $300 \mathrm{~kg} \mathrm{KCl} / \mathrm{ha}$. Hasil penelitian menunjukkan bahwa status hara sebelum penelitian kandungan hara kalium $\left(\mathrm{K}_{\mathrm{dd}}\right)$ 0.18-0.25 me K/100g ${ }^{-1}$ status hara sangat rendah (SR), sehingga menjadi faktor pembatas utama. Berdasarkan minus one test dosis pemupukan optimal bawang merah spesifik lokasi lahan pasir ialah $\mathrm{KCl} 150 \mathrm{~kg} \mathrm{ha}^{-1}$ dengan persen hasil relatif tertinggi (120\%). Akan tetapi respon dosis pemupukan kalium dosis maksimum $250 \mathrm{~kg} / \mathrm{ha}^{-1}$ dengan persamaan kuadratik $\left(\mathrm{R}^{2}=0.556\right)$. Produksi bawang merah maksimal mencapai $15-16 \mathrm{t} / \mathrm{ha}^{-1}$ brangkasan (setara dengan 12.75-13.6 t/ha umbi) dengan rendemen umbi $\pm 15 \%$. Oleh karena itu, dalam implementasinya diperlukan dosis kalium optimal secara spesifik lokasi, tidak dosis umum secara nasional.
\end{abstract}

Kata kunci: lahan pasir, bawang merah, kalium, pupuk NPK

\section{ABSTRACT}

Potassium is one of success key of soil nutrient on shallot production support on south sandy land. The aimed of research is to determine potassium fertilizing respon on shallot in specific location on sandy land. The study was conducted on June-September 2015 and June-September 2016 on Manuggal farmer group, Srigading

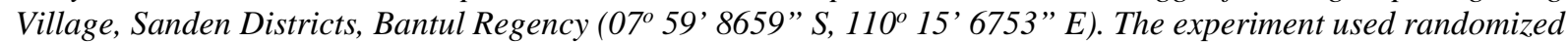
block design with single factor using a with single factor randomized block design with Minus One Test approach consists of 7 sides and control is repeated for 3. Effectivity respons $K$ fertilizer used randomized block design with 5 dose levels of fertilizer treatments $0,75,150,225$, and $300 \mathrm{~kg} \mathrm{KCl/ha}$. The results showed that soil nutrient of potassium $\left(K_{d d}\right)$ is 0,18-0,25 me K/100 $\mathrm{g}^{-1}$ (very low), thus becoming main limiting factor. Minus one test shallot optimal fertilizing dose sandy land specific location is $\mathrm{KCl} 150 \mathrm{~kg} \mathrm{ha^{-1 }}$ with percent result relatively (120\%). However, dose response of potassium with maximum dose is $250 \mathrm{~kg} / \mathrm{ha} \mathrm{I}^{-1}$ of quadratic equations $R^{2} 0,556$. Maximum shallot production reach 15-16 t/ha equivalent with 12,75-13,6 t/ha tuber. Therefore, in its implementation required of optimal dosage of potassium on specific location not general national.

Key words: sandy land, shallot, potassium, N P K fertilization

PENDAHULUAN

Bawang merah termasuk 10

komoditas hortikultura unggulan nasional

yang sedang dipacu produksinya, tahun

2010 diperkirakan kebutuhan mencapai
976.284 ton (Direktorat Jenderal

Pengolahan dan Pemasaran Hasil, 2006).

Produksi bawang merah yang berfluktuasi

turut menyebabkan fluktuasi harga di

pasaran. Target produksi nasional bawang 
merah antara tahun 2005 sampai 2025 diperkirakan meningkat dari 847.883 ton menjadi 1.541.737 ton (Badan Penelitian dan Pengembangan Pertanian, 2005). Diperlukan luas tambah tanam pada lahan sub optimal seperti lahan pasir D.I.Yogyakarta. Salah satu upaya peningkatan produksi bawang merah sangat tergantung pada penyediaan hara tanaman berupa pupuk. Produksi bawang merah tidak hanya dipengaruhi oleh pemupukan saja. Bawang merah untuk tumbuh baik membutuhkan sedikitnya $110 \quad \mathrm{~kg} \quad \mathrm{ha}^{-1}$ kalium (Horneck, 2004) sedangkan rekomendasi Balai Penelitian Tanaman Sayuran Lembang bawang merah membutuhkan sedikitnya $100 \mathrm{~kg} \mathrm{~K} \mathrm{ha}{ }^{-1}$ (Asandhi dkk., 2005 dalam Syukur, et al., 2011) untuk tumbuh baik.

Kalium mempunyai fungsi sangat penting dalam sel tanaman diperlukan untuk proses fotosintesis dalam tanaman (Internasional Rice Research Institute, 2007). Kalium dalam tanah mineral jumlahnya sedikit sehingga diperlukan tambahan dari luar melalui pemupukan. Kalium merupakan salah satu unsur hara yang menjadi kunci keberhasilan dalam mendukung produksi bawang merah. Kalium dalam tanah berada dalam empat bentuk: (1) kation $\mathrm{K}^{+}$larutan tanah, (2) $\mathrm{K}^{+}$ yang dapat dipertukarkan dalam koloid tanah, (3) terikat oleh kisi-kisi lempung (clay) dan (4) komponen mineral yang mengandung K. Ketika pupuk K diaplikasikan pada tanah keseimbangan bergeser kearah K yang dapat dipertukarkan dan terikat, karena $\mathrm{K}$ berpindah dari larutan tanah akibat penyerapan akar. Sebaliknya kalium merupakan nutrisi tanaman yang dibutuhkan dalam jumlah banyak kemudian didistribusikan ke berbagai sel seluruh organ dan memegang peranan penting dalam fungsi sel. Kekurangan $\mathrm{K}$ pada tanaman dapat mempengaruhi pertumbuhan dengan menunjukkan gejala klorosis, pinggir daun mengering, produksi daun berkurang, bentuk daun abnormal, fotosintesis terganggu dan pembentukan karbohidrat berkurang (Brady, 1990) mudah roboh dan berpengaruh terhadap kualitas hasil (Tisdale et al., 1985). Kandungan $\mathrm{K}$ pada tanaman berkisar 1 sampai $5 \%$ dari berat kering jaringan daun dengan nilai kecukupan berkisar 1,5 sampai 3\% dari daun dewasa (Jones, 1998).

Untuk mencapai pertumbuhan dan produksi yang optimal, bawang merah membutuhkan unsur hara $\mathrm{K}$ yang termasuk ke dalam unsur hara esensial selama budidaya. Akan tetapi pemupukan di lahan pasir tingkat efisiensinya rendah karena 50$70 \%$ kalium dari pupuk yang diberikan hilang melalui pencucian, penguapan, imobilisasi mikrobia tanah (Lan et al., 2008). Oleh sebab itu, bawang merah membutuhkan penambahan hara dari luar untuk dapat hidup optimal (Hidayat dan 
Rosliani, 1996) produksi optimal dan kualitas baik. Fairhurst et al. (2007) melaporkan bahwa penyebab kahat K pada lahan pasir kemungkinan disebabkan oleh rendahnya kapasitas pasok $\mathrm{K}$ tanah, ketidakcukupan pemberian pupuk $\mathrm{K}$ anorganik, kecilnya masukan $\mathrm{K}$ dalam air irigasi dan rendahnya efisiensi penyerapan pupuk $\mathrm{K}$ yang diberikan karena tingginya kapasitas pengikatan atau pencucian $\mathrm{K}$. Tanah yang cenderung kahat $\mathrm{K}$ tanah bertekstur kasar dengan KTK rendah dan sedikit cadangan $\mathrm{K}$. Usaha untuk mengatasi permasalahan ketersedian $\mathrm{K}$ dan diperlukan suatu usaha untuk meningkatkan ketersediaan K. Peningkatan ketersediaan K dapat diusahakan dengan pemberian pupuk organik dan pupuk K. Pengelolaan kalium pada tanah pasir (Regosols) perlu ditambahkan dalam bentuk pupuk anorganik seperti $\mathrm{KCl}$ dan asam humit dalam bentuk pupuk organik (kompos) seperti tanah Andisol (Santoso dan Sofyan, 2006).

Daya serap K yang rendah merupakan kendala pemanfaatan tanah mineral seperti jenis tanah Regosols. Keadaan ini menyebabkan pemupukan $\mathrm{K}$ menjadi tidak maksimal atau tidak tepat sesuai dengan kebutuhan tanaman secara spesifik lokasi. Kalium sering menjadi faktor pembatas utama tanah-tanah untuk pertanian, terutama bagi tanaman hortikultura khususnya bawang merah.
Kekurangan $\mathrm{K}$ akibat dosis pemupukan $\mathrm{K}$ yang terlalu rendah akan berdampak pada produksi bawang merah. Selama ini rekomendasi pemupukan kalium dosis pupuk masih bersifat umum belum secara spesifik lokasi, sehingga adanya respon yang berbeda dalam aplikasi di setiap lokasi. Tujuan penelitian untuk mengetahui dosis optimal pupuk kalium pada bawang merah spesifik lokasi lahan pasir.

\section{METODE PENELITIAN}

Penelitian dilaksanakan selama dua tahun di lokasi Kelompok Tani Manunggal, Srigading, Sanden, Bantul (07 59' 8659” S, $110^{\circ} 15^{\prime} 6753$ ” E), pada musim kemarau bulan Juni-September 2016 dan JuniSeptember 2017. Bahan-bahan penelitian berupa varietas bawang merah Porbolinggo (umur simpan 3 bulan), Pupuk organik kotoran sapi, Urea, ZA, SP-36, KCl (dosis Tabel 1 dan Tabel 2), MPHP (mulsa plastik hitam perak) bambu, kayu, papan nama alat ukur, timbangan digital, kantong plastik, alat gambar, alat tulis, dan lain-lainnya (bahan pestisida, fungisida dan perangkap hama). Selain itu alat-alat yang digunakan adalah cultivator dan hand traktor, alat pengedalian OPT (likat kuning, likat putih, likat hijau, Feromon-Exi dan perangkap lampu), pompa air, gembor dan lainlainnya. 
p-ISSN: 1410-0029; e-ISSN2549-6786

Agrin Vol. 21, No. 2, Oktober 2017

Tabel 1. Perlakuan dosis pupuk pada varietas bawang merah Porbolinggo

\begin{tabular}{|c|c|c|c|c|c|c|c|}
\hline Perlakuan & Urea & $\mathrm{ZA}$ & SP-36 & $\mathrm{KCl}$ & $\begin{array}{c}\text { NPK } \\
(15-15-15)\end{array}$ & $\begin{array}{c}\text { NPK } \\
(16-16-16)\end{array}$ & $\begin{array}{c}\text { Pupuk } \\
\text { Organik }\end{array}$ \\
\hline \multicolumn{8}{|c|}{$\mathrm{kg} / \mathrm{ha}^{-1}$} \\
\hline 1. $\quad \mathrm{NP}(-\mathrm{N})$ & & & 150 & 150 & 0 & 0 & 20000 \\
\hline 2. NK (-P) & 150 & 250 & & 150 & 0 & 0 & 20000 \\
\hline 3. NP $(-\mathrm{K})$ & 150 & 250 & 150 & & 0 & 0 & 20000 \\
\hline 4. NPK & 150 & 250 & 150 & 150 & 0 & 0 & 20000 \\
\hline 5. NPK & 197 & 400 & 311 & 224 & 0 & 0 & 20000 \\
\hline $\begin{array}{l}\text { 6. Rekomendasi } \\
\text { Kandungan Hara) } \\
\text { (P dan K Sedang } \\
\text { Tanah mineral) }\end{array}$ & & & & & & & \\
\hline $\begin{array}{l}\text { 7. Rekomendasi BPTP } \\
\text { Yogyakarta }\end{array}$ & 150 & 250 & 150 & 150 & 0 & 0 & 20000 \\
\hline $\begin{array}{l}\text { 8. Dosis petani } \\
\text { (Exsisting) } \\
\text { (eksisting) }\end{array}$ & 100 & 150 & 400 & 300 & 200 & 100 & 20000 \\
\hline 9. Kontrol & 0 & 0 & 0 & 0 & 0 & 0 & 0 \\
\hline \multicolumn{8}{|c|}{ Aplikasi } \\
\hline 1. Preplant & 0.3 & 0.3 & 0.3 & 0.3 & 0.3 & 0.3 & 100 \\
\hline 2. $2 \mathrm{MST}$ (14 hari) & 0.4 & 0.4 & 0.4 & 0.4 & 0.4 & 0.4 & 0 \\
\hline 3. 5 MST (35 hari) & 0.3 & 0.3 & 0.3 & 0.3 & 0.3 & 0.3 & 0 \\
\hline
\end{tabular}

Keterangan: $\mathrm{MST}=$ minggu setelah tanam.

Penelitian dengan pendekatan minus one test pada bawang merah varietas Porbolinggo disusun berdasarkan Rancangan Acak Kelompok, yang terdiri dari 7 taraf dan kontrol perlakuan dosis pupuk (Tabel 1) diulang 4 kali.

Dosis pupuk rekomendasi untuk bawang merah varietas Porbolinggo pada musim penghujan $300 \mathrm{~kg} \mathrm{ZA} \mathrm{ha-1,} 250 \mathrm{~kg}$ SP-36 ha-1 dan $200 \mathrm{~kg} \mathrm{KCl} \mathrm{ha}^{-1}$, sedangkan

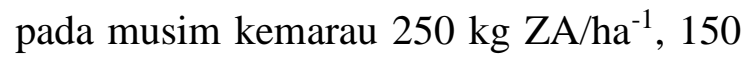
kg Urea ha-1 150 kg SP-36 ha-1 dan 150 kg $\mathrm{KCl} \mathrm{ha}{ }^{-1}$ (Sutardi et al., 2001). Rekomendasi inovasi teknologi ameliorasi pupuk organik 2,5-5 t/ha dan penambahan tanah liat $30-60 \quad \mathrm{~m}^{3} / \mathrm{ha}$ sekali pada pembukaan lahan (Hendarta et al., 2004).
Pengamatan peubah agronomi dilakukan secara acak diagonal masingmasing titik pengamatan 5 tanaman, sehingga 20 tanamam per plot/perlakuan dilakukan saat panen terhadap: bobot kering daun, umbi dan akar, tinggi tanaman nisbah umbi dan unsur hara menjadi pembatas. Nisbah umbi diperoleh perbandingan berat kering umbi dengan berat kering tanaman. Untuk mengetahui unsur hara menjadi pembatas pertumbuhan bawang merah digunakan metode persen hasil relatif (PHR) bobot kering total sebagai berikut:

Hasil perlakuan kurang satu hara PHR “=” -------- x 100\% NPK lengkap 
Tabel 2. Perlakuan dan dosis pupuk N, P, K, dan S pada penelitian pemupukan untuk tanaman bawang merah

\begin{tabular}{lccccc}
\hline Perlakuan & $\begin{array}{c}\text { Urea } \\
\left(\mathrm{kg} \mathrm{ha}^{-1}\right)\end{array}$ & $\begin{array}{c}\text { ZA } \\
\left(\mathrm{kg} \mathrm{ha}^{-1}\right)\end{array}$ & $\begin{array}{c}\text { SP-36 } \\
\left(\mathrm{kg} \mathrm{ha}^{-1}\right)\end{array}$ & $\begin{array}{c}\mathrm{KCl} \\
\left(\mathrm{kg} \mathrm{ha}^{-1}\right)\end{array}$ & $\begin{array}{c}\text { Pupuk kandang } \\
\left(\mathrm{t} \mathrm{ha}^{-1}\right)\end{array}$ \\
\hline K0 & 100 & 250 & 150 & 0 & 20 \\
K1 & 100 & 250 & 150 & 75 & 20 \\
K2 & 100 & 250 & 150 & 150 & 20 \\
K3 & 100 & 250 & 150 & 225 & 20 \\
K4 & 100 & 250 & 150 & 300 & 20 \\
\hline
\end{tabular}

Penelitian uji respon $\mathrm{K}$ menggunakan rancangan acak kelompok dengan 5 perlakuan dan 3 ulangan. Tingkat dosis pupuk K merupakan perlakuan dalam penelitian ini dengan dosis sebagai berikut $0,75,150,225$, dan $300 \mathrm{~kg} \mathrm{KCl} \mathrm{ha}^{-1}$. Selain pupuk $\mathrm{KCl}(65 \%)$ sebagai perlakuan setiap petak percobaan juga ditambah 20 ton $\mathrm{ha}^{-1}$ pupuk kandang, $250 \mathrm{~kg} \mathrm{ha}^{-1} \mathrm{ZA}$, dan $150 \mathrm{~kg}$ $\mathrm{ha}^{-1}$ SP-36. Dosis pupuk yang dicoba disajikan pada Tabel 2.

Pupuk diberikan 3 kali, yaitu pada saat tanaman bawang merah berumur 7 hari setelah tanam dengan 30\% pupuk, 21 hari setelah tanam dengan $40 \%$ pupuk dan 28 hari setelah tanam dengan 30\% pupuk, kecuali pupuk SP-36. Semua pupuk SP-36 diberikan pada umur 7 hari setelah tanam. Bahan organik diberikan sebelum tanam. Bersamaan pemupukan pertama diberi Furadan 7-10 kg/ha ${ }^{-1}$. Petak percobaan dibuat berukuran $6 \mathrm{~m} \times 2 \mathrm{~m}^{2}$, dan diberi mulsa plastik hitam perak (MPHP). Tanaman bawang merah ditanam dengan jarak $20 \mathrm{~cm} \times 20 \mathrm{~cm}^{2}$. Sebelum ditanam, kulit luar benih bawang merah yang mengering dan sisa-sisa akarnya dibuang. Dipilih benih yang sedapat mungkin seragam antara jumlah dan besar umbi dalam satu lubang tanam. Pemeliharaan yang dilakukan sesuai dengan yang biasa dilakukan petani setempat, antara lain, penyiangan, dan penyiraman, serta pemberantasan hama dan penyakit. Panen dilakukan sekitar umur 70 hari setelah tanam, dengan ciri daun mulai menguning, dan ujung daun mulai mengering, pangkal daun atau ujung umbi mengecil dan gembos, umbi merekah keluar dan kulit umbi sudah terbentuk berwarna merah.

Pengamatan dilakukan terhadap contoh tanah sebelum diberi perlakuan, analisis tanah setelah panen, analisis umbi dan daun bawang merah. Contoh tanah sebelum diberi perlakuan diambil pada setiap ulangan (3 contoh), kemudian dijadikan satu sebelum dan setelah panen diambil contoh tanah dan jaringan setiap perlakuan dan dianalisis $\mathrm{K} \mathrm{HCl} 25 \%$ dan $\mathrm{K}$ $\left(\mathrm{NH}_{4} \mathrm{OAc} 1 \mathrm{~N}\right.$ pH 7). Contoh daun dan umbi diambil setelah panen dan dianalisis hara $\mathrm{K}$ total. 
Peubah agronomi pengamatan pertumbuhan dan hasil bawang merah dilakukan secara acak diagonal masingmasing titik pengamatan 10 tanaman dan ubinan. Pengamatan agronomi dilakukan sebanyak tiga kali yaitu pada umur 15 hst, 35 hst dan saat panen (70 hst) terhadap : tinggi tanaman, jumlah umbi tanaman dan produksi per plot. Tingi tanaman dan jumlah umbi diukur dari dari sampel 10 rumpun secara acak pada masing-masing paket teknologi pemupukan dan diamati tiga kali umur 15 hst, 35 hst, dan 70 hst (saat panen). Pengamatan Produksi per plot dilakukan saat panen dengan menimbang produksi berat total, umbi basah, dan daun serta berat kering eskip.

Analisis statistik yang digunakan dalam percobaan ini meliputi analisis secara deskriptif dan sidik ragam pada taraf nyata 5\%. Apabila uji sidik ragam menunjukkan pengaruh beda nyata, maka dilanjutkan dengan Uji Jarak Ganda Duncan (UJGD) pada taraf 5\%. Uji lanjut nilai Regresi $\left(\mathrm{R}^{2}\right)$ dilakukan untuk melihat pembandingan dua nilai tengah di antara masing-masing perlakuan.

\section{HASIL DAN PEMBAHASAN}

\section{Karakteristik Biofisik Tanah Lahan Pasir}

Berdasarkan hasil pemetakan yang dilakukan oleh Pusat Penelitian Tanah dan Agroklimat Bogor (1994) melaporkan bahwa sifat fisik dan kimia tanah pasir dicirikan oleh tekstur pasir, struktur tanah berbutir, konsistensi lepas, sangat porus sehingga daya sangga air dan pupuk yang rendah tergolong lahan marjinal (suboptimal). Hal yang sama Pusat Penelitian Tanah dan Agroklimat 1994, dalam Sudihardjo (2001) dan Sutardi et al., (1998) menyimpulkan bahwa tanah di lahan beting pasir berdasarkan klasifikasi tanah termasuk ordo Entisols, Subordo Psamments, Grup Ustipsamments dan Subgrup Typic Ustipsamments termasuk seri tanah Parangtritis. Agroekologi zona (AEZ) berdasarkan karakterisasi biofisik Typic Ustipsamments mineral campuran, isohipertemik, fisiografi datar, beting pasir, bahan induk endapan eolin, lereng 1-5\%, suhu rata-rata $27,2^{\circ} \mathrm{C}$, curah hujan rata-rata 2500-3000 $\mathrm{mm} / \mathrm{th}$, drainase dan permeabilitas sangat cepat.

Pemberian bahan organik dapat menyatukan butir-butir menjadi agregat mikro dan menyatukan agregat mikro menjadi agregat yang lebih besar. Input pemberian mineral liat dan bahan organik serta lainya telah mengubah komposisi fraksi pasir, debu dan liat di tanah pasir pantai, sehingga berdampak pada perubahan tata udara, padatan dan air. Panambahan mineral liat dan pupuk organik sangat nyata menurunkan berat vulume (BV), akan tetapi berat jenis (BJ) tidak nyata. Partoyo (2005) melaporkan bahwa 
penambahan lempung dan pupuk kandang di lahan pasir pantai menurunkan BJ dan BV. Hal tersebut menyebabkan faktor pembatas sifat fisik tanah didominasi oleh tekstur pasir yang berakibat daya pegang air dan hara rendah, sehingga cenderung daya pegang air dan hara lebih baik dibandingkan tanah aslinya. Partoyo (2005) menyimpulkan bahwa perlakuan penambahan tanah lempung dan pupuk kandang pada lahan pertanian di lahan pasir pantai Bulak Tegalrejo, Samas, Bantul dapat memperbaiki kualitas tanah. Perbaikan kualitas tanah tersebut dapat ditunjukkan dengan meningkatnya indeks kualitas tanah. Produktivitas tanah dapat dilihat dari aspek C-organik, KTK, tekstur dan warna (Tabu et al., 2005). Menurut Kastono (2007) penggunaan lempung dan bahan organik dapat memperbaiki struktur dan pori mikro. Perubahan perbandingan tekstur pasir akan berkurang persentasenya sehingga tekstur debu dan liat menambah daya pegang air dan hara lebih baik. Rajiman et al. (2008) menyimpulkan bahwa penggunaan pembenah tanah (jenis tanah, bahan organik dan limbah karbit) telah meningkatkan jumlah fraksi debu dan lempung serta menurunkan fraksi pasir dibanding kontrol namun belum mampu mengubah klas tekstur dari kontrol yang bertekstur pasiran. Perubahan fraksi pasir menurun $>2 \%$ diikuti peningkatan fraksi debu $>2 \%)$ dan liat $(0,25-0,50 \%)$. Sutardi dan Mulyadi (2016) melaporkan bahwa sifat kimia tanah dicerminkan oleh $\mathrm{pH}$ dan C-organik, kandungan $\mathrm{P}_{2} \mathrm{O}_{5}$ tinggi, kandungan $\mathrm{N}$-total, dan $\mathrm{K}$-dd sangat rendah pada lahan pasir. Sifat fisik tanah terutama persentase tekstur pasir besar (98\%), sedangkan debu, diikuti oleh BV, namun persentase tekstur liat sedikit.

\section{Uji Minus One Test}

\section{Pertumbuhan Tanaman}

Berdasarkan analisis ragam perlakuan minus one test hara $\mathrm{N}, \mathrm{P}$ dan $\mathrm{K}$ di lahan pasir berpengaruh nyata terhadap tinggi dan persen hasil relatif. Berdasarkan persen hasil relatif pada setiap bahwa perlakuan N,-P dan -K, serta N.P.K (lengkap) unsur hara kalium dan nitrogen merupakan faktor pembatas utama hara tanaman pada lahan pasir spesifik lokasi (Tabel 3). Persen hasil relatif (PHR) $<100 \%$ menunjukkan bahwa $\mathrm{N}$ sangat dibutuhkan, kemudian $\mathrm{P}$ dan $\mathrm{K}$ $(54,50 \%, 84,25 \%$ dan 92.5\%). Perlakuan $\mathrm{N}$, -P dan $-\mathrm{K}$ berbeda nyata dibandingkan dengan kontrol, walaupun -P dan -K tidak berbeda nyata dengan NPK, akan tetapi nilai PHR $<100 \%$.

Defisiensi $\mathrm{K}$ dapat menghambat pertumbuhan, penurunan ketahanan dari penyakit, dan menurunkan hasil bawang merah (Singh \& Verma, 2001). Menurut Woldetsadik (2003) pemberian K mempengaruhi pertumbuhan, hasil dan kualitas umbi. Tanah lahan pasir mempunyai kandungan hara $\mathrm{K}_{\mathrm{dd}}$ 0.18- 0.25 
me $\mathrm{K} / 100 \mathrm{~g}^{-1}$ katergori klas sangat rendah, sehingga kebutuhan kalium belum dapat terpenuhi dari kandungan hara dalam tanah.

Untuk mengetahui faktor pembatas salah satu unsur hara terhadap pertumbuhan tanaman bawang merah dilakukan uji UJGD pada taraf $0.05 \%$ seperti yang disajikan pada Tabel 3.

\section{Produksi}

Berdasarkan uji UJGD bahwa komponen hasil bobot umbi per rumpun dan produksi per plotnya berbeda nyata, sedangkan jumlah umbi dan bobot daun tidak nyata. Produksi umbi per plot dan per ha berbeda nyata ini terbukti bahwa perlakuan pupuk memberikan hasil yang berbeda-beda (Tabel 4). Produksi kekurangan salah satu unsur $\mathrm{N}, \mathrm{P}$ dan $\mathrm{K}$ berbeda nyata dibandingkan dengan kontrol, meskipun -K produksinya (19.982 $\left.\mathrm{kg} \mathrm{ha}^{-1}\right)$ lebih rendah $(720 \mathrm{~kg} / \mathrm{ha}$ atau $5,6 \%)$ dibandingkan dengan perlakukan NPK $\left(20.712 \mathrm{~kg} \mathrm{ha}^{-1}\right)$.

Berdasarkan parameter komponen produksi dapat disimpulkan bahwa dosis $150 \mathrm{~kg} \mathrm{ha}^{-1} \mathrm{KCl}$ memberikan produksi yang optimal bila dibandingan paket teknologi pemupukan NPK serta perlakuan lainnya. Pemupukan dengan dosis pupuk kalium yang lebih tinggi teryata belum tentu dapat diikuti oleh kenaikan produksi yang maksimal, sehingga menyebabkan efisiensinya rendah. Berdasarkan uji paket pemupukan bahwa pupuk berimbang dengan dosis perbandingan N, P dan K yang tepat dan rasional memberikan efisiensi lebih baik, ini terbukti produksinya maksimal.

Tabel 3. Tinggi tanaman, bobot kering daun,umbi, akar, nisbah umbi, dan persen hasil relative dengan aplikasi dosis pupuk berbeda

\begin{tabular}{|c|c|c|c|c|c|c|}
\hline Perlakuan & $\begin{array}{l}\text { Tinggi } \\
\text { Tanaman } \\
(\mathrm{cm})\end{array}$ & $\begin{array}{l}\text { Bobot } \\
\text { kering } \\
\text { daun }(g)\end{array}$ & $\begin{array}{l}\text { Bobot } \\
\text { kering } \\
\text { umbi } \\
(\mathrm{g})\end{array}$ & $\begin{array}{l}\text { Bobot } \\
\text { kering } \\
\operatorname{akar}(g)\end{array}$ & $\begin{array}{l}\text { Nisbah } \\
\text { umbi } \\
(\%)\end{array}$ & $\begin{array}{l}\text { Persen } \\
\text { hasil } \\
\text { relatif } \\
(\%)\end{array}$ \\
\hline Kontrol & $25,25 b$ & 3,13 & 45,55 & 0,26 & 60,50 & $55,75 b$ \\
\hline PK (-N) & $28,00 \mathrm{ab}$ & 4,72 & 43,03 & 0,28 & 67,25 & $54,50 \mathrm{~b}$ \\
\hline NK (-P) & $34,25 \mathrm{ab}$ & 5,71 & 70,02 & 0,31 & 67,75 & $84,25 \mathrm{a}$ \\
\hline$N P(-K)$ & $34,25 \mathrm{ab}$ & 6,18 & 77,49 & 0,31 & 78,00 & $92,50 \mathrm{a}$ \\
\hline NPK & $32,50 \mathrm{ab}$ & 5,26 & 74,86 & 0,29 & 73,25 & $100,00 \mathrm{a}$ \\
\hline $\begin{array}{l}\text { NPK Rekomendasi } \\
\text { kandungan hara (P dan } \mathrm{K} \\
\text { sedang tanah mineral) }\end{array}$ & $34,50 \mathrm{ab}$ & 4,87 & 62,82 & 0,25 & 69,00 & $77,50 \mathrm{a}$ \\
\hline $\begin{array}{l}\text { Rekomendasi } \\
\text { Yogyakarta }\end{array}$ & $36,50 \mathrm{a}$ & 9,26 & 78,54 & 0,21 & 72,50 & $91,50 \mathrm{a}$ \\
\hline Dosis petani (Exsisting) & $34,75 \mathrm{ab}$ & 7,24 & 83,00 & 0,30 & 68,50 & $95,00 \mathrm{a}$ \\
\hline KK & 12,90 & 52,10 & 32,50 & 25,20 & 16,30 & 25,7 \\
\hline
\end{tabular}

Keterangan: Angka yang diikuti huruf yang sama $(a, b)$ pada baris yang sama menunjukkan tidak beda nyata berdasar Uji Jarak Ganda Duncan (UJGD) pada taraf 5\%. 
Tabel 4. Jumlah umbi/rumpun, bobot daun,umbi, produksi per plot dan produksi umbi/ha dengan aplikasi dosis pupuk berbeda

\begin{tabular}{lrrrrr}
\hline Perlakuan & $\begin{array}{l}\text { Jumlah } \\
\text { Umbi/ } \\
\text { Rumpun }\end{array}$ & $\begin{array}{l}\text { Bobot } \\
\text { daun/ } \\
\text { rumpun } \\
(\mathrm{g})\end{array}$ & $\begin{array}{l}\text { Bobot } \\
\text { umbi/ } \\
\text { rumpun } \\
(\mathrm{g})\end{array}$ & $\begin{array}{l}\text { Produksi } \\
\text { perplot } \\
(\mathrm{kg})\end{array}$ & $\begin{array}{l}\text { Produksi } \\
\text { umbi/ha }\end{array}$ \\
$(\mathrm{kg})$
\end{tabular}

Keterangan: Angka yang diikuti huruf yang sama pada baris yang sama menunjukkan tidak beda nyata berdasar Uji Jarak Ganda Duncan (UJGD) pada taraf 5\%.

Berdasarkan parameter komponen produksi dapat disimpulkan bahwa dosis $150 \mathrm{~kg} \mathrm{ha}^{-1} \mathrm{KCl}$ memberikan produksi yang optimal bila dibandingan paket teknologi pemupukan NPK serta perlakuan lainnya. Pemupukan dengan dosis pupuk kalium yang lebih tinggi teryata belum tentu dapat diikuti oleh kenaikan produksi yang maksimal, sehingga menyebabkan efisiensinya rendah. Berdasarkan uji paket pemupukan bahwa pupuk berimbang dengan dosis perbandingan $\mathrm{N}, \mathrm{P}$ dan $\mathrm{K}$ yang tepat dan rasional memberikan efisiensi lebih baik, ini terbukti produksinya maksimal.

\section{Persen Hasil Relatif}

Berdasarkan persen hasil relatif pada setiap perlakuan N, P dan K (lengkap) dan rekomendasi pemupukan dapat ditentukan seperti yang disajikan pada Tabel 5 menunjukkan bahwa nilai $<100 \%$ dibandingkan dengan perlakuan NPK lengkap merupakan faktor pembatas salah satu unsur untuk pertumbuhan dan produksi. Berdasarkan peubah rata-rata persen hasil relatif tinggi tanaman, nisbah umbi, berat umbi dan produksi umbi dapat disimpulkan bahwa faktor pembatas tertinggi adalah kalium. Kebutuhan K untuk bawang merah belum terpenuhi dari suber kandungan mineral hara dalam tanah tersebut. Kekurangan salah satu unsur kalium berdampak terhadap berat umbi dan produksi umbi per hektar (Tabel 5). Berdasarkan persen hasil relatif tertinggi diperoleh pada dosis pemupukan kalium $150 \mathrm{~kg} \mathrm{ha}^{-1}$. 
Tabel. 5 Persen hasil relatif pada tinggi tanaman saat panen nisbah umbi, bobot umbi/rumpun dan produksi umbi per ha dengan aplikasi dosis pupuk berbeda

\begin{tabular}{lcrcc}
\hline \multicolumn{1}{c}{ Perlakuan } & $\begin{array}{c}\text { Tinggi } \\
\text { tanaman }\end{array}$ & $\begin{array}{c}\text { Nisbah } \\
\text { umbi }\end{array}$ & $\begin{array}{r}\text { Bobot umbi } \\
\text { per rumpun }\end{array}$ & $\begin{array}{c}\text { Produksi } \\
\text { umbi ha }\end{array}$ \\
\hline Kontrol & 78 & 83 & 56 & 57 \\
PK (-N) & 86 & 92 & 55 & 77 \\
NK (-P) & 102 & 92 & 84 & 107 \\
NP (-K) & 105 & 106 & 93 & 96 \\
NPK & 100 & 100 & 100 & 100 \\
NPK Rekomendasi kandungan hara & 106 & 94 & 78 & 120 \\
(P dan K sedang tanah mineral) & & & & \\
Rekomendasi BPTP & 112 & 99 & 92 & 120 \\
Dosis petani (Exsisting) & 107 & 94 & 103 & 108 \\
\hline
\end{tabular}

Keterangan: Nilai persen hasil relative $<100 \%$ indikator kekurangan salah satu unsur hara.

Hasil analisis rerata produksi brangkasan, umbi $\mathrm{kg} / \mathrm{ha}$ dan persen hasil relatif tertinggi parameter perlakuan NPK rekomendasi kandungan hara $\mathrm{P}$ dan $\mathrm{K}$ sedang tanah mineral dengan $\mathrm{KCl} 224$ kg/ha. Berdasarkan uji Minus One Test dapat diketahui bahwa urutan tingkat faktor pembatas unsur $\mathrm{K}$ menjadi utama pada lahan pasir. Woldetsadik (2003) menyatakan bahwa kalium dalam tanah sering ditemui sebagai faktor pembatas, karena K merupakan unsur hara yang sangat peka terhadap pencucian terutama di daerah tropis dengan curah hujan yang tnggi. Kalium diserap oleh tanaman dalam jumlah yang cukup besar atau bahkan kadangkadang melebihi jumlah nitrogen terutama pada tanaman umbi-umbian, walaupun kalium tersedia terbatas (Woldetsadik, 2003). Kalium berfungsi menjaga status air tanaman dan tekanan turgor sel, mengatur stomata dan mengatur akumulasi dan translokasi karbohidrat yang baru terbentuk. Pemberian $\mathrm{K}$ pada bawang merah mempengaruhi pertumbuhan hasil dan kualitas umbi (Akhtar et al., 2002).

\section{Uji Respons Kalium}

Uji respon pemupukan hara $\mathrm{K}$ pada lahan tanah pasir terhadap peubah tinggi tanaman dan jumlah umbi tidak berbeda nyata, akan tetapi cenderung lebih tinggi dibandingkan dengan pemupukan $\mathrm{K}$ dapat meningkatkan tinggi tanaman (Tabel 6) dan jumlah umbi (Tabel 7). Walaupun kadar K dalam tanah sangat rendah. Pemupukan K memperbaiki pertumbuhan dan jumlah umbi. Terbukti hasil pengamatan tinggi tanaman dan jumlah umbi pada umur 15 hst, 30 hst, dan 70 hst lebih baik yang dipupuk $\mathrm{K}$ pada dosis $75,150,220$, dan $300 \mathrm{~kg} / \mathrm{ha}^{-1}$ $\mathrm{KCl}$ lebih baik dibandingkan dengan kontrol (Tabel 6).

Pemupukan hara $\mathrm{K}$ pada lahan pasir terlihat dapat meningkatkan berat brangkasan (umbi+daun) bawang merah. Peningkatan berat brangkasan bawang merah tertingggi terjadi pada penambahan pupuk $\mathrm{KCl} 250 \mathrm{~kg} \mathrm{ha}^{-1}$ dan pada 
Tabel 6. Tinggi tanaman bawang merah pada pemupukan hara K pada lahan berpasir dengan aplikasi dosis pupuk K berbeda

\begin{tabular}{cccc}
\hline \multirow{2}{*}{$\begin{array}{c}\text { Pemupukan K } \\
(\mathrm{kg} \mathrm{KCl} / \mathrm{ha})\end{array}$} & \multicolumn{3}{c}{ Tinggi tanaman bawang merah $(\mathrm{cm})$ pada umur } \\
\cline { 2 - 4 } & $15 \mathrm{HST}$ & $30 \mathrm{HST}$ & $70 \mathrm{HST}$ \\
\hline 0 & 14,68 & 36,78 & 37,00 \\
150 & 18,19 & 38,45 & 38,43 \\
220 & 16,28 & 36,10 & 36,60 \\
300 & 15,72 & 36,98 & 38,10 \\
& 15,78 & 35,82 & 36,53 \\
\hline
\end{tabular}

Keterangan: Angka yang diikuti oleh huruf yang sama pada baris yang sama tidak berbeda nyata Uji Jarak Ganda Duncan (UJGD) pada taraf 5\%.

Tabel 7. Jumlah umbi bawang merah pada pemupukan hara $\mathrm{K}$ pada tanah berpasir

\begin{tabular}{cccc}
\hline \multirow{2}{*}{$\begin{array}{c}\text { Pemupukan K } \\
\text { (kg KCl/ha) }\end{array}$} & \multicolumn{3}{c}{ Jumlah umbi bawang merah pada umur } \\
\cline { 2 - 4 } & 15 HST & 30 HST & HST \\
75 & 2,87 & 4,77 & 6,20 \\
150 & 2,93 & 5,23 & 6,23 \\
220 & 3,37 & 5,57 & 6,56 \\
300 & 3,10 & 5,97 & 7,17 \\
\end{tabular}

Keterangan: Angka yang diikuti oleh huruf yang sama pada baris yang sama tidak berbeda nyata Uji Jarak Ganda Duncan (UJGD) pada taraf 5\%

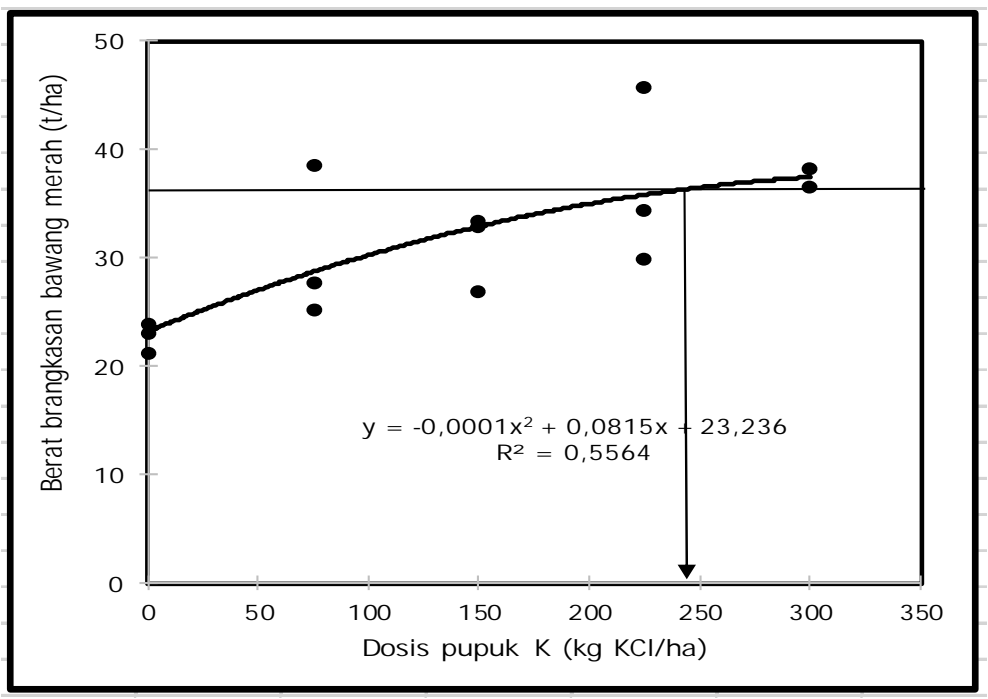

Gambar 1. Berat brangkasan bawang merah pada tanah pasir dengan aplikasi dosis pupuk K berbeda.

penambahan dosis yang lebih tinggi cenderung melandai. Dengan demikian dapat dikatakan bahwa dosis optimum pupuk $\mathrm{KCl}$ untuk pertumbuhan dan produksi bawang merah pada lahan pasir adalah $250 \mathrm{~kg} \mathrm{ha}^{-1}$. Pertumbuhan dan hasil bawang merah meningkat secara bertahap dengan meningkatnya jumlah pemberian pupuk $\mathrm{K}$, walaupun pemberian $\mathrm{K}$ tidak memberikan pengaruh yang nyata terhadap pertumbuhan. Hara K sangat diperlukan dalam pembentukan, pembesaran, dan pemanjangan umbi. Menurut Napitupulu dan Winarto (2010), pemberian pupuk K 
memberikan pengaruh yang sangat nyata dalam meningkatkan hasil bawang merah. Hal yang sama Kalwia et al., (2015) melaporkan bahwa dosis pupuk $\mathrm{K}$ berpengaruh nyata terhadap semua parameter pertumbuhan kecuali jumlah anakan dan luas daun, serta semua parameter hasil yaitu jumlah umbi perumpun, diameter umbi, berat segar umbi, berat kering umbi dan produksi. Dimana dengan dosis pupuk $100 \mathrm{~kg} \mathrm{~K} / \mathrm{ha}$ dan $250 \mathrm{~kg} \mathrm{~K} /$ ha menunjukan hasil produksi yang lebih tinggi dibandingkan perlakuan lainnya.

Kadar Unsur $\mathrm{K}_{2} \mathrm{O}_{5}$ Sebelum Tanam, Sesudah Panen dan Jaringan Tanaman

Berdasarkan hasil analisis, kadar unsur $\mathrm{K}_{2} \mathrm{O}_{5}$ tertinggi terdapat pada perlakuan $300 \mathrm{~kg} \mathrm{ha}^{-1}$, terendah perlakuan $150 \mathrm{~kg} \mathrm{ha}{ }^{-1} \mathrm{KCl}$, namun hasil analsis sesudah panen terjadi perubahan kadarnya, tertinggi pada perlakuan $220 \mathrm{~kg} \mathrm{ha}^{-1}$ dan terendah tanpa (kontrol) perlakuan pupuk kalium (Tabel 8).
Hasil analsis jaringan kadar $\mathrm{K}_{2} \mathrm{O}_{5}$ besarnya tergantung pada pupuk Kalium yang diberikan, semakin besar pupuk kalium kadar $\mathrm{K}_{2} \mathrm{O}_{5}$ jaringan lebih besar yaitu kontrol (1.40\%), $75 \mathrm{~kg} \mathrm{ha}^{-1} \mathrm{KCl}(1.42 \%)$, $150 \mathrm{~kg} \mathrm{ha}^{-1} \mathrm{KCl}(1,50), 220 \mathrm{~kg} \mathrm{ha}^{-1} \mathrm{KCl}$ $(1,62)$ dan $300 \mathrm{~kg} \mathrm{ha}^{-1} \mathrm{KCl}$ sebesar $(1,82$ $\%)$. Bentuk unsur $\mathrm{K}$ lambat tersedia dan kandungannya dalam tanah berbeda-beda, tergantung dari bahan induknya serta derajat pelapukan tanah. Pada saat panen, unsur $\mathrm{K}_{2} \mathrm{O}_{5}$ yang menjadi penyebabnya adalah adanya efek sisa (residual effect). Kandungan $\mathrm{K}_{2} \mathrm{O}_{5}$ pada sisa tanaman berkisar dari $0,5 \%$ sampai $2,0 \%$. Sekiranya yang disimpan itu dibongkar maka unsur K akan tersedia kembali. Faktor lain yang menjadikan unsur $\mathrm{K}$ dalam tanah adalah air irigasi yang diberikan kepada tanaman, sebab air irigasi merupakan salah satu sumber unsur kalium. Air irigasi untuk bawang merah pada lahan pasir bersumber dari air tanah dangkal digunkan untuk penyiraman setiap harinya.

Tabel 8. Kadar unsur K sebelum, sesudah, dan jaringan pada uji respon pupuk $\mathrm{KCl}$

\begin{tabular}{cccc}
\hline $\begin{array}{c}\text { Pemupukan } \\
(\mathrm{kg} \mathrm{KCl} / \mathrm{ha})\end{array}$ & \multicolumn{3}{c}{$\begin{array}{c}\text { Kadar hara } \mathrm{K}_{2} \mathrm{O}_{5}(\%) \\
\text { Eks } \mathrm{HNO}_{3}+\mathrm{HClO}_{4}\end{array}$} \\
\cline { 2 - 4 } & $\begin{array}{c}\text { Tanah sebelum tanam } \\
\left(\mathrm{mg} / 100 \mathrm{~g}^{-1}\right)\end{array}$ & $\begin{array}{c}\text { Tanah sesudah panen } \\
(\%)\end{array}$ & $\begin{array}{c}\text { Jaringan tanaman } \\
(\text { daun+umbi) saat panen } \\
(\%)\end{array}$ \\
\hline 0 & 22,0 & 9,01 & 1,40 \\
75 & 15,0 & 9,08 & 1,42 \\
150 & 9,0 & 10,11 & 1,50 \\
220 & 10,3 & 10,13 & 1,62 \\
300 & 22,3 & 11,04 & 1,82 \\
\hline
\end{tabular}

Sumber: Laboratorium BPTP Yogyakarta dan INSTIPER Yogyakarta. 


\section{KESIMPULAN}

Kesimpulan penelitian ini adalah dosis pemupukan bawang merah berdasarkan pendekatan minus one test dan uji respon lahan pasir dosis optimal $250 \mathrm{~kg}$ $\mathrm{ha}^{-1} \mathrm{KCl}$ spesifik lokasi lahan pasir dengan dosis $\mathrm{N}$ dan $\mathrm{P}$ sesuai rekomendasi.

\section{UCAPAN TERIMA KASIH}

Ucapan terima kasih kedua saya sampaikan kepada SMARTD Satker Badan Penelitian dan Pengembangan Pertanian yang telah berkenan memberikan kesempatan, dana dan kerjasama sehingga penulis dapat melaksanakan kegiatan penelitian ini dengan baik (KKP3SL).

\section{DAFTAR PUSTAKA}

Akhtar, M.E; K. Bashir, M. Z. Khan and K.M. Khokhar. 2002. Effect of Potash Application on Yield of Different Varieties of Onion (Allium ascalonicum. L). Asian Journal of Plant Sciences, 1 (4): 324-3251.

Badan Penelitian dan Pengembangan Pertanian. 2005. Prospek dan arah Pengembangan Agribisnis Bawang Merah. Departemen Pertanian, Jakarta.

Brady, NC. 1990. The Nature and Properties of soil $10^{\text {th }}$ Ed. Macmillan, New York.

Direktorat Jenderal Pengolahan dan Pemasaran Hasil Pertanian. 2006. Road Map Pasca Panen, Pengolahan dan Pemasaran Hasil Bawang Merah. Departemen Pertanian, Jakarta.
Fairhurst, T., C. Witt, R. Buresh dan A. Doberman. 2007. Panduan Praktis Pengelolaan Hara. Internasinal Plant Nutrition Institute dan Internasional Potash Institute. 96 hal.

Hendarta, R, M. Fatchurrochim, Sutardi, Mulyadi, Supriyadi, T. Martini, E. Wisnu, Sukar, T. Djafar, B. Setyono dan Sutarno. 2004. Rekomendasi Teknologi Pertanian Provinsi D.I. Yogyakarta. Komisi Pengkajian Teknologi Pertanian Propinsi DIY.

Hidayat, Y dan R. Rosliani. 1996. Pengaruh Pemupukan N, P dan K Pada Pertumbuhan dan Produksi Bawang Merah Kultivar Sumenep. Jurnal Hortikultura, 5 (5): 39-43.

Horneck, D.A. 2004. Nutrient management for onions in the Pacific Northwest. Better Crops, 88 (1): 14-16.

Internasional Rice Research Institute. 2007. Panduan Praktis Pengelolaan Hara. . Internasinal Plant Nutrition Institute dan Internasional Potash Institute. Edisi kedua 2007. 96 hal.

Jones, J.B. 1998. Plant Nutrition Manual. CRC Press, New York.

Kalwia H.Y.U., H. Barus dan I.S. Madauna. 2015. Pengaruh Ukuran Umbi dan Dosis Kalium terhadap Pertumbuhan dan Hasil Produksi Bawang Merah (Allium ascalonicum L.) Varietas Lembah Palu. Jurnal Agrotekbis, 3 (6): 655- 661.

Kastono, D. 2007. Aplikasi Model Rekayasa Lahan Terpadu Guna Meningkatkan Produksi Hortikultura secara Berkelanjutan di Lahan Pasir Pantai. Jurnal Ilmu-ilmu Pertanian, 3(2):112-123.

Lan, W., M. Liu and R. Liang. 2008. Preparation and Properties of a Double-Coated Slow-Release NPK Compound Fertilizer with Superabsorbent and Water-Retention. Bioresource Technology, 99: 547554. 
Napitupulu, D. dan L. Winarto. 2010. Pengaruh Pemberian Pupuk N dan K terhadap Pertumbuhan dan Produksi Bawang Merah. Jurnal Hortikultura. 20(1): 27-35.

Partoyo. 2005. Analisis Indeks Kualitas Tanah Pertanian di Lahan Pasir Pantai Samas Yogyakarta. Jurnal Ilmu Pertanian, 12 (2): 140 - 151.

Pusat Penelitian Tanah dan Agroklimat. 1994. Survei Tanah Detail di Sebagian Wilayah D.I. Yogyakarta (skala 1 : 50.000). Proyek LREP II Part C. Puslittanak. Bogor.

Rajiman, Y. Prapto, S. Endang dan H. Eko. 2008. Pengaruh Pembenah Tanah terhadap Sifat Fisika Tanah dan Hasil Bawang Merah pada Lahan Pasir Pantai Bugel Kabupaten Kulon Progo. Jurnal Agrin 12 (1): 67-77.

Santoso, D. dan A. Sofyan. 2006. Pengelolaan Hara Tanaman pada Lahan Kering. Proc Teknologi Pengelolaan Lahan kering Menuju Pertanian Produktif dan Ramah Lingkungan. Pusat Penelitian dan Pengembangan Tanah dan Agroklimat. Badan Litbaang Pertanian. pp 73- 100.

Singh, S.P. and A.B. Verma, 2001. Response of Onion (Allium cepa) to Potassium Application. Indian Journal of Agronomy, 46: 182-185.

Sudihardjo, A.M. 2001. Budidaya Tanaman Bawang di Lahan Beting Pasir Pantai Selatan Yogyakarta untuk Mendukung Pengembangan Wilayah. Prosiding Seminar Nasional Teknologi Pertanian Pendukung Agribisnis dalam Pengembangan Ekonomi Wilayah. Puslit Sosek Pertanian, BPTP Yogyakarta - Univ. Pembangunan Nasional "Veteran " Yogyakarta.

Sutardi, H. Ngadimin dan Budiono. 1998. Penerapan Analisis Spesifik Lokasi Berdasarkan Zone Agroekosistem
Tingkat Tinjau 1 : 300.000 dan Semi detail 1 : 50.000 D.I. Yogyakarta. Prosiding Seminar Ilmiah dan Lokakarya. Teknologi Spesifik Lokasi dalam Pengembangan Pertanian dengan Orientasi Agribisnis. BPTP Ungaran, PSE Bogor. Badan Litbang Pertanian. Hal $5-11$.

Sutardi, Sarjiman dan Budiono. 2001. Uji Adaptasi Kultivar Bawang Merah Pada Musim Hujan dan Kemarau di Propinsi D.I Yogyakarta. Prosiding Seminar Usaha Peningkatan Ketahanan Pangan di Jawa Tengah. Semarang 15 Nopember 2000. Pusat Penelitian Sosial Ekonomi. Badan Litbang Pertanian. Hal 8 - 93.

Sutardi dan Mulyadi. 2016. Pengaruh Pemupukan $-N,-P$ dan $-K$ serta Macam Dosis Rekomendasi Spesifik Lokasi Lahan Pasir Pantai D.I.Yogyakarta. Prosiding Teknologi Pertanian Spesifik Lokasi. IAARD Press 2016. Hal 149-164.

Syukur, A., Sulakhudin dan B.H. Sunarminto. 2011. Pengaruh Pupuk NPK Berlapis Zeo-Hukalsi Terhadap Pertumbuhan dan Hasil Bawang Merah di Tanah Pasir Pantai Bugel Kulon Progo. Agrin, 15(1): 64-75.

Tabu, I.M., R.K. Obura, A. Bationo and L. Nakhone. 2005. Effect of Farmers' Management Practices on Soil Properties and Maize Yield. Journal Agronomy, 4 (4): 293-299.

Tisdale S.L., W.L. Nelson and J.D. Beaton. 1985. Soil Fertility and Fertilizer $4^{\text {th }}$ Edition. Macmilan Publishing Campany, New York.

Woldetsadik, K. 2003. Shallot (Allium cepa var. ascolonicum) Responses to Plant Nutrient and Soil Moisture in a Subhumit Tropical Climate. Doctoral Diss. Dept. Of Crop Science, SLU. Acta Universitatis Agriculturae Sueciae. 